\title{
Genetic heterogeneity in breast cancer: the road to personalized medicine?
}

Richard D Baird ${ }^{1 *}$ and Carlos Caldas ${ }^{1,2^{*}}$

\begin{abstract}
More women die from breast cancer across the world today than from any other type of malignancy. The clinical course of breast cancer varies tremendously between patients. While some of this variability is explained by traditional clinico-pathological factors (including patient age, tumor stage, histological grade and estrogen receptor status), molecular profiling studies have defined breast cancer subtypes with distinct clinical outcomes. This minireview considers recent studies which have used genomics technologies in an attempt to identify new biomarkers of prognosis and treatment response. These studies highlight the genetic heterogeneity that exists within breast cancers in space and time.
\end{abstract}

Keywords: Breast cancer, Next-generation sequencing, Whole-genome sequencing, Molecular profiling, Personalized medicine, Heterogeneity

\section{The genetic heterogeneity seen in breast cancer has important clinical implications}

In 2008 it was estimated that the annual number of new breast cancer diagnoses globally was approximately 1.4 million, with just under half a million deaths. It has long been recognized that the clinical course of breast cancer varies tremendously between patients. Traditional clinicopathological variables, including tumor stage, grade and estrogen receptor status, have been used for decades by clinicians to help prognosticate and guide treatment of their patients. In the last 30 years or so, a range of molecular biology technologies, including gene expression profiling, have been used to define molecular subgroups of breast cancer with distinct clinical outcomes [1-3]. These studies have identified recurrent somatic abnormalities, including gene mutations, copy number aberrations and translocations, the most important of which has been the ERBB2 amplification present in 15 to $20 \%$ of breast cancers [4]. This mini-review considers recent studies that have used genomic technologies in an attempt to identify

\footnotetext{
*Correspondence: richard.baird@medschl.cam.ac.uk; carlos.caldas@cruk.cam.ac.uk

'Department of Oncology, University of Cambridge, Addenbrooke's Hospital, Hills Road, Box 97, Cambridge CB4 3EJ, UK

${ }^{2}$ Cancer Research UK Cambridge Research Institute, Li KaShing Centre, Robinson Way, Cambridge CB2 ORE, UK
}

new biomarkers of prognosis and treatment response for patients with breast cancer.

\section{Recent next-generation sequencing studies}

Whole-genome sequencing studies have reported tens of thousands of somatic mutations in different cancers [5-7]. The evidence suggests that only a small minority of these are essential for cancer development ("driver mutations") with the majority having no significant biological impact ("passenger mutations") [8]. In the clonal evolution model of malignant progression first proposed in 1976 by Nowell [9], different cancer clones within a tumor are in constant competition, with the "fittest" clones proliferating at the expense of "less fit" clones. Key driver mutations are thought to provide a selective advantage on a cell to facilitate its clonal expansion [9].

The degree of genetic heterogeneity within tumors from individual patients in both space and over time is increasingly well characterized [10]. In one early report using whole-genome sequencing, Shah et al. examined paired, metachronous tumors from a single patient with advanced invasive lobular carcinoma of the breast, and found 19 non-synonymous mutations present in metastatic tumors that were not evident in the primary tumor diagnosed nine years earlier [11].

Nik-Zainal et al. characterized the molecular profiles of 21 primary breast cancers in terms of copy number 
changes, genomic rearrangements and whole genome sequencing $[12,13]$. The authors used "most-recent common ancestor" bioinformatics algorithms to infer changes in mutation signatures over time. A key finding from these studies was that each tumor contained a dominant clone ( $>50 \%$ of cancer cells) which had a mutational profile very different from those of other sub-clones [12].

Shah et al. examined genome aberrations in a series of 104 primary "triple-negative" breast cancers using Affymetrix SNP6.0 arrays, RNA-seq and genome/exome sequencing. These tumors are so called "triple-negative" because they lack estrogen receptor, progesterone receptor and ERBB2 amplification [14]. This study showed beyond doubt that this "catch-all" diagnosis of exclusion in fact refers to a group of cancers that exhibit great genetic heterogeneity. Interestingly, the abundance of somatic mutations in a given tumor did not correlate with the proportion of the genome with copy number alterations (CNAs).

Stephens et al. analyzed the genomes of 100 tumors for copy number alterations and mutations in coding exons of protein-coding genes [15]. The authors found correlations among the number of somatic mutations, the age at which cancer was diagnosed and tumor histological grade. New driver mutations were found in nine cancer genes including: AKT2, ARIDIB, CASP8, CDKN1B, MAP3K1, MAP3K13, NCOR1, SMARCD1andTBX3 [15].

Banerji et al. focused on the use of whole exome sequencing to identify patterns of mutation and translocation from 103 breast cancers from a range of subtypes [16]. The authors confirmed the presence of PIK3CA, TP53, AKT1, GATA3 and MAP3K1 mutations, but also identified a recurrent $M A G I 3-A K T 3$ fusion found most commonly in ER/PR-negative, HER2-negative breast cancers. Functional experiments showed that this fusion gene caused constitutive activation of AKT kinase which was amenable to therapy with a selective, small-molecular AKT inhibitor [16].

In the largest breast cancer series reported to date, the METABRIC study group performed an integrated analysis of copy number and gene expression in discovery and validation sets each containing approximately 1,000 primary breast tumors, with long-term clinical follow-up [17]. Inherited genetic variants (single nucleotide polymorphisms (SNPs) and copy number variants (CNVs)), and acquired somatic CNAs were associated with altered gene expression in approximately $40 \%$ of genes. Importantly, analysis of the combined DNA-RNA profiles revealed 10 different sub-groups with distinct clinical outcomes, which reproduced in the validation cohort. These included subgroups not previously identified by first-generation gene expression profiling studies, in particular with seven distinct subtypes of ER positive disease and a separation of triple negative cancers into at least two subtypes [1]. Indeed, there is increasing evidence that diagnosis of "triple negative" breast cancer does not describe a single biological entity with distinct natural history. Rather, it refers to a wide range of cancers with great genetic diversity, which can be further classified into multiple subtypes [18]. In one study, the functional heterogeneity observed within the stem-cell-like compartment of triple-negative breast cancers revealed a 31-gene signature which was associated with the development of metastatic disease [19].

In addition to studies using genomic techniques to identify prognostic biomarkers, a number of studies are emerging focused on the identification of biomarkers that predict response to therapies. For example, Ellis et al. performed whole exome and whole genome sequencing on 31 and 46 samples collected in two neoadjuvant aromatase inhibitor trials [20]. The most significant such finding was that mutant GATA3 appeared to correlate with treatment-induced anti-proliferative effect [20].

Table 1 Most frequently mutated breast cancer genes

\begin{tabular}{|c|c|c|c|c|c|c|}
\hline \multirow[b]{2}{*}{ Gene mutation } & \multirow[b]{2}{*}{ Function } & \multicolumn{5}{|c|}{ Approximate mutation frequency (\%) } \\
\hline & & Overall & Luminal A & Luminal B & HER2-enriched & Basal-like \\
\hline PIK3CA & $\begin{array}{l}\text { catalytic subunit of PI3 kinase; key signal transduction } \\
\text { enzyme involved in cellular growth, survival } \\
\text { and insulin signaling }\end{array}$ & $25-36$ & $40-45$ & 29 & 39 & 9 \\
\hline TP53 & $\begin{array}{l}\text { tumor suppressor; key regulator of cell cycle, } \\
\text { DNA repair, apoptosis }\end{array}$ & $27-37$ & 12 & 29 & 72 & 80 \\
\hline GATA3 & $\begin{array}{l}\text { transcription factor which regulates luminal epithelial cell } \\
\text { differentiation in the mammary gland }\end{array}$ & $4-11$ & 14 & 15 & 2 & 2 \\
\hline MAP3K1 & kinase that activates ERK and JNK kinase pathways & $3-8$ & 13 & 5 & 4 & 0 \\
\hline MLL3 & $\begin{array}{l}\text { histone-lysine } \mathrm{N} \text {-methyltransferase involved in transcriptional } \\
\text { co activation }\end{array}$ & 7 & 8 & 6 & 7 & 5 \\
\hline $\mathrm{CDH1}$ & $\begin{array}{l}\text { cell-cell adhesion glycoprotein; loss-of-function mutations } \\
\text { in E-cadherin are a feature of lobular breast cancer }\end{array}$ & 7 & $9-10$ & 5 & 5 & 0 \\
\hline
\end{tabular}

Summary of data from recent breast cancer sequencing studies cited in this mini-review [14-17,20,21]. 
The most recent large breast cancer sequencing study to be published is that of the Cancer Genome Atlas Network [21]. The investigators analyzed tumor and germline DNA samples from 825 primary breast cancers using orthogonal techniques, with different subsets of patients assayed on each of the following platforms: genomic DNA copy number arrays, DNA methylation, exome sequencing, mRNA arrays, microRNA sequencing and reverse-phase protein arrays. Analysis of the combined data from five platforms suggested there were four main breast cancer classes, with each of these subgroups characterized by significant molecular heterogeneity. Once again this study confirmed that there were relatively few "high-frequency" somatic mutations, with only three genes (TP53, PIK3CA and GATA3) occurring at $>10 \%$ incidence across all breast cancers. Table 1 summarizes the most common mutations found in recent large sequencing studies of breast cancer. Intriguingly, comparison of basal-like breast tumors with high-grade serous ovarian cancers uncovered many molecular similarities. The authors concluded that "much of the clinically observable plasticity and heterogeneity occurs within, and not across, the major biological subtypes of breast cancer". However, when the cancers were classified into the 10 subtypes identified in METABRIC there were clear patterns of cluster-specific mutational landscapes emerging, providing strong support for the new molecular taxonomy of breast cancer.

It is important to note that high-quality next-generation sequencing (NGS) studies are characterized by stringent quality control measures, and study designs that include enough patient samples for accurate assessment of lowprevalence findings. NGS technologies continue to evolve rapidly, driven by the requirement to reduce assay times and cost, while providing sufficient depth and coverage [22].

\section{The need for repeat tumor biopsies}

Clinical studies of tumor heterogeneity at the molecular level, and clonal evolution over time, have been hampered in the past by difficulties in accessing repeated tumor samples from different anatomical areas, and at different timepoints. Future studies may be facilitated by two recent developments. First, for patients with metastatic breast cancer, it is increasingly recognized that ER and HER2 status can change over time, and that in selected cases, repeat tumor biopsy is indicated on clinical grounds to determine whether ER or HER2-targeted therapy should be considered [23]. Secondly, it may prove clinically useful to take serial blood samples to sequence circulating tumor DNA (ctDNA), as a less-invasive "liquid biopsy" [24]. New ctDNA assays may have advantages over circulating tumor cells, including greater sensitivity in monitoring tumor response to therapy [25], and a strategy by which to elucidate mechanisms of drug resistance in the clinic [26].

\section{Conclusion: the best therapeutic strategy. All-out war? Magic bullets? Or uneasy stalemate?}

In contrast to metastatic breast cancer, Hodgkin's lymphoma, testicular cancer and acute myeloid leukemia can be cured using aggressive chemotherapy. However, this is not true for the common metastatic solid tumors. Indeed, high-dose chemotherapy strategies were pursued unsuccessfully by many researchers in an attempt to completely eradicate all cancer cells in a patient's body [27]. These strategies failed, some authors argue, because of the tremendous genetic heterogeneity of cancers, their spatial dispersion and adaptation to myriad local microenvironments within the individual patient [28]. The suggestion is that for oncologists to achieve the best possible outcomes for their patients, there should be a fundamental change to the canonical treatment approach. Eradication of a dominant, chemosensitive clone may serve only to increase the selective pressure within the tumor, leading to expansion of chemoresistant clones. Rather than killing the maximum number of cells possible, these authors suggest we should be trying to kill the fewest necessary to prevent tumor progression [28]. Others point to drug resistance mechanisms which might be overcome through identification of novel drug targets, the development of new targeted therapies and the rational use of drug combinations $[29,30]$. One thing, however, is clear; if we are to achieve the promise of personalized medicine, clinical trials will need to follow (with adequate patient numbers) the genetic diversity within tumors which exists in space and time, in relation to the outcomes achieved following different systemic therapies.

\section{Abbreviations \\ CNAs: Copy number alterations; CNVs: Copy number variants; ER: Estrogen receptor; ERBB2: Erythroblastic leukemia viral oncogene homolog 2; HER2: Human epidermal growth factor 2; NGS: Next-generation sequencing; SNPs: Single nucleotide polymorphisms.}

\section{Competing interests}

The authors declared that they have no competing interests.

\section{Authors' contributions}

$\mathrm{RB}$ and $\mathrm{CC}$ jointly wrote the manuscript. Both authors read and approved the final manuscript.

\section{Authors' information}

$\mathrm{RB}$ is Academic Consultant in Experimental Cancer Therapeutics at the University of Cambridge, and Honorary Consultant Medical Oncologist at Cambridge University Hospitals NHS Foundation Trust. His principal research interest is in the development of novel cancer therapeutics and diagnostics for patients with breast cancer.

CC is Professor of Cancer Medicine at the University of Cambridge, Senior Group Leader at the Cancer Research UK Cambridge Institute, and Honorary Consultant Medical Oncologist at Cambridge University Hospitals NHS

Foundation Trust. He is also Lead for the Cambridge Experimental Cancer Medicine Centre and Director of the Cambridge Breast Cancer Research Unit.

\section{Acknowledgements}

We acknowledge the support of Cancer Research UK, the University of Cambridge, National Institute for Health Research Cambridge Biomedical Research Centre and Cambridge Experimental Cancer Medicine Centre. 
Received: 21 December 2012 Accepted: 29 May 2013

Published: 18 June 2013

\section{References}

1. Sørlie T, Perou CM, Tibshirani R, Aas T, Geisler S, Johnsen H, Hastie T, Eisen MB, van de Rijn M, Jeffrey SS, Thorsen T, Quist H, Matese JC, Brown PO, Botstein D, Lønning PE, Børresen-Dale AL: Gene expression patterns of breast carcinomas distinguish tumor subclasses with clinical implications. Proc Natl Acad Sci U S A 2001, 98:10869-10874.

2. Chin K, DeVries S, Fridlyand J, Spellman PT, Roydasgupta R, Kuo WL, Lapuk A, Neve RM, Qian Z, Ryder T, Chen F, Feiler H, Tokuyasu T, Kingsley C, Dairkee S, Meng Z, Chew K, Pinkel D, Jain A, Ljung BM, Esserman L, Albertson DG, Waldman FM, Gray JW: Genomic and transcriptional aberrations linked to breast cancer pathophysiologies. Cancer Cell 2006, 10:529-541.

3. Gatza ML, Lucas JE, Barry WT, Kim JW, Wang Q, Crawford MD, Datto MB, Kelley M, Mathey-Prevot B, Potti A, Nevins JR: A pathway-based classification of human breast cancer. Proc Natl Acad Sci U S A 2010, 107:6994-6999.

4. Ross JS, Slodkowska EA, Symmans WF, Pusztai L, Ravdin PM, Hortobagyi GN: The HER-2 receptor and breast cancer: ten years of targeted anti-HER-2 therapy and personalized medicine. Oncologist 2009, 14:320-368.

5. Ding L, Ellis MJ, Li S, Larson DE, Chen K, Wallis JW, Harris CC, McLellan MD, Fulton RS, Fulton LL, Abbott RM, Hoog J, Dooling DJ, Koboldt DC, Schmidt H, Kalicki J, Zhang Q, Chen L, Lin L, Wendl MC, McMichael JF, Magrini VJ, Cook L, McGrath SD, Vickery TL, Appelbaum E, Deschryver K, Davies S, Guintoli T, Lin L, et al: Genome remodelling in a basal-like breast cancer metastasis and xenograft. Nature 2010, 464:999-1005.

6. Chapman MA, Lawrence MS, Keats JJ, Cibulskis K, Sougnez C, Schinzel AC, Harview CL, Brunet J-P, Ahmann GJ, Adli M, Anderson KC, Ardlie KG, Auclair D, Baker A, Bergsagel PL, Bernstein BE, Drier Y, Fonseca R, Gabriel SB, Hofmeister CC, Jagannath S, Jakubowiak AJ, Krishnan A, Levy J, Liefeld T, Lonial S, Mahan S, Mfuko B, Monti S, Perkins LM, et al: Initial genome sequencing and analysis of multiple myeloma. Nature 2011, 471:467-472.

7. Pleasance ED, Cheetham RK, Stephens PJ, McBride DJ, Humphray SJ, Greenman CD, Varela I, Lin M-L, Ordóñez GR, Bignell GR, Ye K, Alipaz J, Bauer MJ, Beare D, Butler A, Carter RJ, Chen L, Cox AJ, Edkins S, KokkoGonzales PI, Gormley NA, Grocock RJ, Haudenschild CD, Hims MM, James T, Jia M, Kingsbury Z, Leroy C, Marshall J, Menzies A, et al: A comprehensive catalogue of somatic mutations from a human cancer genome. Nature 2010, 463:191-196.

8. Stratton MR: Exploring the genomes of cancer cells: progress and promise. Science 2011, 331:1553-1558.

9. Nowell PC: The clonal evolution of tumor cell populations. Science 1976, $194: 23-28$.

10. Gerlinger M, Rowan AJ, Horswell S, Larkin J, Endesfelder D, Gronroos E, Martinez P, Matthews N, Stewart A, Tarpey P, Varela I, Phillimore B, Begum S, McDonald NQ, Butler A, Jones D, Raine K, Latimer C, Santos CR, Nohadani M, Eklund AC, Spencer-Dene B, Clark G, Pickering L, Stamp G, Gore M, Szallasi Z, Downward J, Futreal PA, Swanton C: Intratumor heterogeneity and branched evolution revealed by multiregion sequencing. $N$ Engl J Med 2012, 366:883-892.

11. Shah SP, Morin RD, Khattra J, Prentice L, Pugh T, Burleigh A, Delaney A, Gelmon K, Guliany R, Senz J, Steidl C, Holt RA, Jones S, Sun M, Leung G, Moore R, Severson T, Taylor GA, Teschendorff AE, Tse K, Turashvili G, Varhol R, Warren RL, Watson P, Zhao Y, Caldas C, Huntsman D, Hirst M, Marra MA, Aparicio S: Mutational evolution in a lobular breast tumour profiled at single nucleotide resolution. Nature 2009, 461:809-813.

12. Nik-Zainal S, Van Loo P, Wedge DC, Alexandrov LB, Greenman CD, Lau KW, Raine K, Jones D, Marshall J, Ramakrishna M, Shlien A, Cooke SL, Hinton J, Menzies A, Stebbings LA, Leroy C, Jia M, Rance R, Mudie LJ, Gamble SJ, Stephens PJ, McLaren S, Tarpey PS, Papaemmanuil E, Davies HR, Varela I, McBride DJ, Bignell GR, Leung K, Butler AP, et al: The life history of 21 breast cancers. Cell 2012, 149:994-1007.

13. Nik-Zainal S, Alexandrov LB, Wedge DC, Van Loo P, Greenman CD, Raine K, Jones D, Hinton J, Marshall J, Stebbings LA, Menzies A, Martin S, Leung K, Chen L, Leroy C, Ramakrishna M, Rance R, Lau KW, Mudie L, Varela I, McBride DJ, Bignell GR, Cooke SL, Shlien A, Gamble J, Whitmore I, Maddison M, Tarpey PS, Davies HR, Papaemmanuil E, et al: Mutational processes molding the genomes of 21 breast cancers. Cell 2012, 149:979-993.
14. Shah SP, Roth A, Goya R, Oloumi A, Ha G, Zhao Y, Turashvili G, Ding J, Tse K, Haffari G, Bashashati A, Prentice LM, Khattra J, Burleigh A, Yap D, Bernard V, McPherson A, Shumansky K, Crisan A, Giuliany R, Heravi-Moussavi A, Rosner J, Lai D, Birol I, Varhol R, Tam A, Dhalla N, Zeng T, Ma K, Chan SK, et al: The clonal and mutational evolution spectrum of primary triple-negative breast cancers. Nature 2012, 486:395-399.

15. Stephens PJ, Tarpey PS, Davies H, Van Loo P, Greenman C, Wedge DC, NikZainal S, Martin S, Varela I, Bignell GR, Yates LR, Papaemmanuil E, Beare D, Butler A, Cheverton A, Gamble J, Hinton J, Jia M, Jayakumar A, Jones D, Latimer C, Lau KW, McLaren S, McBride DJ, Menzies A, Mudie L, Raine K, Rad R, Chapman MS, Teague J, et al: The landscape of cancer genes and mutational processes in breast cancer. Nature 2012, 486:400-404.

16. Banerji S, Cibulskis K, Rangel-Escareno C, Brown KK, Carter SL, Frederick AM, Lawrence MS, Sivachenko AY, Sougnez C, Zou L, Cortes ML, FernandezLopez JC, Peng S, Ardlie KG, Auclair D, Bautista-Piña V, Duke F, Francis J, Jung J, Maffuz-Aziz A, Onofrio RC, Parkin M, Pho NH, Quintanar-Jurado V, Ramos AH, Rebollar-Vega R, Rodriguez-Cuevas S, Romero-Cordoba SL, Schumacher SE, Stransky N, et al: Sequence analysis of mutations and translocations across breast cancer subtypes. Nature 2012, 486:405-409.

17. Curtis C, Shah SP, Chin S-F, Turashvili G, Rueda OM, Dunning MJ, Speed D, Lynch AG, Samarajiwa S, Yuan Y, Gräf S, Ha G, Haffari G, Bashashati A, Russell R, McKinney S, METABRIC group, Langerød A, Green A, Provenzano E, Wishart G, Pinder S, Watson P, Markowetz F, Murphy L, Ellis IO, Purushotham $A$, Børresen-Dale A- $L$, Brenton JD, Tavaré $S$, Caldas $C$, et al: The genomic and transcriptomic architecture of 2,000 breast tumours reveals novel subgroups. Nature 2012, 486:346-352.

18. Lehmann BD, Bauer JA, Chen $X$, Sanders ME, Chakravarthy AB, Shyr $Y$, Pietenpol JA: Identification of human triple-negative breast cancer subtypes and preclinical models for selection of targeted therapies. J Clin Invest 2011, 121:2750-2767.

19. Leth-Larsen R, Terp MG, Christensen AG, Elias D, Kühlwein T, Jensen ON, Petersen OW, Ditzel HJ: Functional heterogeneity within the CD44 high human breast cancer stem cell-like compartment reveals a gene signature predictive of distant metastasis. MolMed 2012, 18:1109-1121.

20. Ellis MJ, Ding L, Shen D, Luo J, Suman VJ, Wallis JW, Van Tine BA, Hoog J Goiffon RJ, Goldstein TC, Ng S, Lin L, Crowder R, Snider J, Ballman K, Weber J, Chen K, Koboldt DC, Kandoth C, Schierding W, McMichael JF, Miller CA, Lu C, Harris CC, McLellan MD, Wendl MC, DeSchryver K, Allred DC, Esserman L, Unzeitig $\mathrm{G}$, et al: Whole-genome analysis informs breast cancer response to aromatase inhibition. Nature 2012,486:353-360.

21. Cancer Genome Atlas N, Koboldt DC, Fulton RS, McLellan MD, Schmidt H, Kalicki-Veizer J, McMichael JF, Fulton LL, Dooling DJ, Ding L, Mardis ER, Wilson RK, Ally A, Balasundaram M, Butterfield YSN, Carlsen R, Carter C, Chu A, Chuah E, Chun H-JE, Coope RJN, Dhalla N, Guin R, Hirst C, Hirst M, Holt RA, Lee D, Li HI, Mayo M, Moore RA, Mungall AJ, et al: Comprehensive molecular portraits of human breast tumours. Nature 2012, 490:61-70.

22. Meyerson M, Gabriel S, Getz G: Advances in understanding cancer genomes through second-generation sequencing. Nat Rev Genet 2010, 11:685-696.

23. Aurilio G, Disalvatore D, Bagnardi V, Munzone E, Adamoli L, Curigliano G, Pruneri G, Sciandivasci A, De Vita F, Goldhirsch A, Nole F: A meta-analysis of receptor status discordance between primary breast cancer and metastases. 2012 ASCO Annual Meeting. J Clin Oncol 2012, 30:Abstract No 546.

24. Forshew T, Murtaza M, Parkinson C, Gale D, Tsui DW, Kaper F, Dawson S-J, Piskorz AM, Jimenez-Linan M, Bentley D, Hadfield J, May AP, Caldas C, Brenton JD, Rosenfeld N: Noninvasive identification and monitoring of cancer mutations by targeted deep sequencing of plasma DNA. SciTrans/ Med 2012, 4:136ra68.

25. Dawson S-J, Tsui DW, Murtaza M, Biggs H, Rueda OM, Chin S-F, Dunning MJ, Gale D, Forshew T, Mahler-Araujo B, Rajan S, Humphray S, Becq J, Halsall D, Wallis M, Bentley D, Caldas C, Rosenfeld N: Analysis of circulating tumor DNA to monitor metastatic breast cancer. N Engl J Med 2013, 368:1199-1209.

26. Murtaza M, Dawson S-J, Tsui DW, Gale D, Forshew T, Piskorz AM, Parkinson C, Chin S-F, Kingsbury Z, Wong ASC, Marass F, Humphray S, Hadfield J, Bentley D, Chin TM, Brenton JD, Caldas C, Rosenfeld N: Non-invasive analysis of acquired resistance to cancer therapy by sequencing of plasma DNA. Nature 2013, 497:108-112.

27. Farquhar C, Marjoribanks J, Basser R, Hetrick S, Lethaby A: High dose chemotherapy and autologous bone marrow or stem cell 
transplantation versus conventional chemotherapy for women with metastatic breast cancer. Cochrane Database Syst Rev 2005. CD003142.

28. Gatenby RA: A change of strategy in the war on cancer. Nature 2009, 459:508-509.

29. Baird RD, Kaye SB: Drug resistance reversal-are we getting closer? Eur J Cancer 2003, 39:2450-2461.

30. Yap TA, Sandhu SK, Workman P, De Bono JS: Envisioning the future of early anticancer drug development. Nat Rev Cancer 2010, 10:514-523.

doi:10.1186/1741-7015-11-151

Cite this article as: Baird and Caldas: Genetic heterogeneity in breast cancer: the road to personalized medicine?. BMC Medicine 2013 11:151.

\section{Submit your next manuscript to BioMed Central and take full advantage of:}

- Convenient online submission

- Thorough peer review

- No space constraints or color figure charges

- Immediate publication on acceptance

- Inclusion in PubMed, CAS, Scopus and Google Scholar

- Research which is freely available for redistribution 